\title{
Northrop Frye e il potere della parola
}

Francesco Guardiani

- You haven't looked beyond the second volume of The Great Code?

- That's about it, that's the main thing ... I don't know where I'll be after that. (42)

Così si conclude l'intervista a Frye di Imre Salusinszky. La conversazione risale al settembre dell'85, cinque anni prima della pubblicazione di Words with Power e sei prima della morte dello studioso avvenuta il 23 gennaio scorso. Ma già dall'82, l'anno di The Great Code, il secondo studio sul rapporto tra la Bibbia e la letteratura era "the main thing" per Frye, visto che proprio nelle pagine introduttive di quel libro annunciava "a second volume in active preparation" (xi). I pochi dati intorno alla genesi di Words with Power, a cui molti altri recentemente raccolti da John Ayre si potrebbero aggiungere (385-394), attestano la lunga e assidua meditazione dello studioso a monte di questo che egli certamente sentiva come il suo ultimo libro, l'ultima prova di un'idea della letteratura sviluppata nell'arco di mezzo secolo, l'estremo messaggio ai suoi lettori (numerosissimi: l'Istituto per l'Informazione Scientifica di Filadelfia, in un rapporto sugli autori più citati nel 1977-78 condotto sulla base di 150.000 pubblicazioni contenenti 900.000 citazioni, ha reso noto che Frye è stato il più citato dopo Marx, Aristotele, Shakespeare, Lenin, Platone, Freud e Roland Barthes; nello stesso rapporto, tra le opere più citate di autori del ventesimo secolo, al primo posto è risultata Anatomy of Criticism [Ayre 372]). Mi pare che la natura del messaggio di congedo in Words with Power si intoni bene con l'idea della sintesi: questo libro contiene una riaffermazione, nei termini più espliciti e persuasivi, di una teoria della letteratura coerentemente articolata dall'epoca del primo grande lavoro, Fearful Symmetry: $A$ Study of William Blake, che è del 1947. Si può dire, anzi, che da allora Frye è stato un critico "ripetitivo"; ma ecco, non si finisce di pronunciare questo termine che subito occorre assegnargli il giusto valore. È Frye stesso che lo chiarisce:

A writer has increasingly less that is radically new to say unless he has previously been wrong. One of my less perceptive reviewers remarked recently that I seemed to be rewriting my central myth in every book I produced. I certainly do, and would never read or trust any writer who did not also do so. But one hopes for some growth in lucidity, or at least an increase of the presbyopia that normally comes in later life, as one proceeds. (The Critical Path 9)

Più che a ogni altro libro di Frye, l' "aumentata lucidità" e, soprattutto, la più consapevole "lungimiranza" sono ben poste in esergo a questo Words with 
Power in cui ancora una volta e per l'ultima volta l'intero sistema letterario, "the order of words" per usare un suo sintagma ricorrente, è chiamato a rivelare il suo codice, "the Great Code of Art" (The Great Code xvi) che gli dà forma e vita.

Indubbiamente quella di Frye è stata una vita accademica laboriosa e felice, piena di esaltanti scoperte e verifiche; è stata anche una vita piena di soddisfazioni di altro tipo, legate alla ricezione del suo lavoro. Tra queste, non ultima, l'aver trovato un devoto e competentissimo studioso come Robert Denham che si è occupato della sistemazione bibliografica dell'immmenso corpus dei suoi scritti (circa ottocento titoli) oltre che della sua fortuna critica. Ebbene, proprio alla solerzia del Denham si deve l'altro importante volume fryeano apparso nel 1990, Myth and Metaphor. Il volume comprende ventiquattro saggi scritti fra il 1974 e il 1988. Propongo di leggerli come pause riflessive nel corso della elaborata stesura di The Great Code e, soprattutto, di Words with Power. Così, mentre è soprattutto di quest'ultimo che qui si discute, si fanno anche costanti, se pur rapidi, riferimenti ai "selected essays". È utile ricordare che tra questi ci sono anche quasi tutti i dodici saggi già apparsi in italiano nel 1989 in Mito metafora simbolo, di cui sulle pagine di questa stessa rivista si è data comunicazione a suo tempo (vol. XI, n. 1, 1990, 168-9).

C'è un ultimo punto prima di entrare nel vivo della lettura di Words with Power. 11 volume è diviso in due parti, ognuna di quattro capitoli la cui numerazione è comunque progressiva da $1 \mathrm{a} 8$. La struttura è identica a quella di The Great Code dove, anzi, il modulo quaternario è più nettamente dichiarato dalla titolazione dei capitoli ("Language I", "Myth l", "Metaphor I", "Typology I"; “Typology II”, "Metaphor II”, "Myth II", "Language II”). Sono anche quattro, va ricordato, i saggi che compongono Anatomy of Criticism. Il modulo viene da Blake, dai Four Zoas della grande epica incompiuta, che sono poi in relazione con le sue quattro parti del cosmo (Cielo, Paradiso terrestre, Terra, Inferno) di cui si parla praticamente in ogni libro di Frye. Sottolineo il tipo di partizione dei tre più importanti libri dello studioso perché essa è consciamente caricata dal simbolismo di Blake.

Il nucleo teorico da cui si espande la riflessione critica del primo capitolo, "Sequence and Mode", è il principio del significato polisemous. È utile ricordare che su tale principio di esegesi medievale (Frye si richiama direttamente ai passi di Dante nella lettera a Cangrande e nel Convivio) era impostata la discussione dei criteri fondamentali dell'analisi critica sia in Anatomy of Criticism che in The Great Code. Penso che la dichiarata "maggior lucidità" dell'ultima trattazione (Words with Power) possa essere meglio compresa tenendo conto di quanto enunciato nelle altre due opere teoriche precedenti. In Anatomy of Criticism tale principio serve per indicare la valenza multipla del simbolo, inteso come unità minima analizzabile di un prodotto verbale: simbolo come "segno-motivo", "immagine", "archetipo", "monade". Dai diversi contesti, o livelli, emergono diverse visioni o teorie della letteratura e quindi 
varie tendenze critiche. Tra queste, precisa comunque lo studioso, soltanto a quelle informate dalle ultime due fasi del simbolo (come archetipo o monade) si può riconoscere la capacità di dare un senso globale a tutta la letteratura come ordine autonomo di parole, "order of words", e quindi la possibilità di studiarne aspetti particolari nell'esperienza pratica ricollegandoli ad una unità generale. Sono costretto qui a generalizzare, il riferimento è comunque ai saggi centrali di Anatomy of Criticism e in particolare a "Theory of Symbols" (69-128).

La costruzione polisemica ritorna in The Great Code, in "Language I" $\mathrm{e}$ "Language Il", i capitoli estremi che quindi abbracciano praticamente il corpo dell'intero volume. Mentre in Anatomy of Criticism il significato polisemous si riferisce al simbolo, qui esso è inteso come base della metafora. Una rapida e schematica ricostruzione delle fasi della trasformazione del linguaggio ispirata dai cicli storici di Vico (ma "in what finally emerged for me very little of Vico was left", egli avverte, 5), porta lo studioso a formulare nel modo seguente le diverse valenze della metafora. Si ha innanzitutto la totale identificazione tra soggetto e oggetto; gli esempi includono le "similitudini" di Omero con le identificazioni verbali dei personaggi mitologici come Apollo-Sole, Nettuno-Mare etc. che egli chiama "ready-made metaphors". La formula che identifica questa metafora è allora "this is that". Che si distingue dalla metafora della seconda fase in cui essa è intesa in maniera allegorica, "this is put for that"; per esempio ci si può riferire al linguaggio di Dante: pensiamo alla "lupa" che "sta per" avarizia. La terza e ultima fase è quella della metafora "indebolita" da un rapporto di "mera" somiglianza tra soggetto e oggetto, espressa dalla formula "this is like that", in cui il figurato è rappresentabile da una miriade di figuranti alla maniera, per intenderci, della metafora barocca. A voler riassumere in maniera ancor più succinta, con i vantaggi (e i rischi: ma bastino a limitar questi i riferimenti ai testi fryeani) di un'estrema generalizzazione, si può qui parlare di: 1) metafora vera e propria; 2) metonimia; 3) similitudine. Ciò che conta è che mentre "l'anima del traslato" è sempre presente, in ogni fase la differenziazione permette di stabilire dei criteri utili e, anzi, per Frye indispensabili, nel lavoro pratico dell'analisi critica. Tali criteri sono parte di un disegno generale, di una base comune che è termine di riferimento per una nuova consapevolezza del processo conoscitivo. La "scala" che va dall'esperienza di lettura alla conoscenza è discussa nelle pagine conclusive di The Great Code.

All'inizio di Words with Power, con un chiarimento sulla natura dei "livelli" o "fasi" (e, in generale su tutte le categorie critiche da lui impiegate), Frye ripropone la teoria del significato polisemous:

I have drawn heavily on it, especially on Dante's formulation of it, in other writings. The theory is usually bound up with the metaphor of levels, a hierarchical metaphor used for convenience, less likely to be misleading when we remember that it refers to a mental diagram in our minds that we have imposed on the subject, not to something inherent in the subject. (4) 
Con questa premessa ben si intende la libertà con cui ora si mettono a fuoco i diversi livelli del linguaggio nella sua totalità "narrativa", e cioè del mito nella primaria accezione del termine (Anatomy of Criticism, "Glossary" 366). E bene si intende, da qui, il rilievo del significato polisemous in questa come nelle altre due opere maggiori: esso è cercato nel simbolo in Anatomy of Criticism, nella metafora in The Great Code, nel mito in Words with Power. Simbolo, metafora e mito sono gli elementi portanti della teoria critica di Frye: il mito, come storia, insieme di storie interrelate in modo da formare una mitologia, un universo che è il vero mondo dei valori umani; la metafora, come linfa vitale del mito, segno dell'identità umana e della coerenza del mondo creato dall'immaginazione; il simbolo, come unità minima di percezione comune (Myth and Metaphor, "Symbol as a Medium of Exchange" 28-43), di umanizzazione della realtà esterna attraverso l'ineluttabile processo connotativo.

"Sequence and Mode", il capitolo con cui si apre Words with Power, è in effetti una sequenza di "modi" che sono qui intesi come strutture verbali "with different emphases on meaning" (3). Al primo livello incontriamo il linguaggio descrittivo in cui la preoccupazione dello scrivente è di fornire informazioni sulla realtà esterna. Giochi di parole e ambiguità di ogni genere sono qui eliminate o studiatamente contenute perché "il vero" è ciò che corrisponde ai fatti nudi e crudi. Abbiamo questo linguaggio quando la replica verbale dell'oggetto di attenzione è ritenuta soddisfacente; senza quest'intesa non si potrebbe neanche avviare il discorso su ciò che chiamiamo "storia", "politica", "democrazia".

I am not suggesting that history, much less what is now called historicity, is simply a verbal imitation of external events, only that without the descriptive double focus of verbal and actual events we should not have what we now call history.

The descriptive writer is a democratic writer, and his truth depends on his putting all his cards on the table, sharing what he knows at every point with his reader.

It is not a coincidence that the techniques of descriptive writing and the theory of democracy grew up together, beginning perhaps around the time of Locke. (6)

La forza che tiene in piedi la struttura descrittiva, ma che allo stesso tempo rimane "largely unexamined" perché si dà per scontata, è la grammatica, la necessità di allineare le parole in un ordine significante. Una forza del genere, determinante ma sottintesa in ogni tipo di articolazione verbale, assume per la ricerca di Frye un rilievo particolare; essa è definita "excluded initiative" (7), sintagma che in italiano forse meglio si può rendere con "iniziativa nascosta" più che "esclusa".

Nel linguaggio di secondo tipo, definito "concettuale", l'iniziativa nascosta è nella coscienza del potere del discorso nel collegare elementi verbali intesi come idee (e non fatti come in precedenza): 
These are expressed in such terms as time, nature, substance, being, all which are necessarily abstract, related immediately to the verbal costruct itself and withdrawn to some degree from the external world. (10)

L'inevitabile ambiguità del discorso (intesa come mancanza di perfetta corrispondenza dei termini a oggetti reali) non è quindi un ostacolo qui, ma una forza costruttiva, positiva nelle sue generalizzazioni. Siamo, insomma, nell'ambito della logica, della dialettica, che ha fondamentalmente un carattere impersonale basato su corrispondenze tra valori astratti, cioè dedotti da una realtà generale.

Un breve passo da qui ci porta alla costituzione di valori creduti e impugnati da ogni individuo della comunità in cui il messaggio verbale è creato ed a cui è rivolto. Il linguaggio concettuale allora si trasforma da impersonale in personale, da logico in retorico:

Whatever the role of dialectic or logical consistency in the Republic, it emerges as a personal vision from the mind of Socrates. We have moved into a third mode here, based on the identity of the writer with what he writes. I say writer, but in this area the ideal is speaking rather than writing. (15)

Rhetoric expresses and appeals to a more comprehensive enlisting of the personality than simple argument: it is not an imitation of dialectic, but an incorporation of it into another mode. (16)

The most elaborate developments of our third mode are the great framework of accepted (and by the great majority unexamined) assumptions that we call ideologies. These are normally structures of social authority... When an established social authority insists that certain ideological postulates are essential, and it is ready to move in on any dissidents who publicly proclaim a different attitude, the subordinating of dialectic to something else is clear enough. (15-16)

L'iniziativa nascosta in questo terzo modo del linguaggio è dunque l'ideologia, o meglio la pressione sull'individuo ad accettare, a credere e ad agire secondo un determinato codice di valori dialetticamente stabilito.

Dopo aver ripercorso la "scala" del trivium, in cui ogni passaggio comprende quello o quelli precedenti, Frye definisce un quarto linguaggio, il più inclusivo, il linguaggio dell'immaginazione che è proprio della letteratura. Qui "the distinction between the emotional and the intellectual has disappeared... ordinary consciousness is only one of the many possible psychic elements, the fantastic and the dreamlike having conventionally equal status" (22). L'iniziativa nascosta a questo livello è il mito. Come Frye ci aveva già insegnato in Anatomy of Criticism la letteratura è "displaced mythology"; ciò che non si discute, che si dà per scontato nella letteratura è che essa ha a che fare con i nostri bisogni primari i quali sono espressi dal mito.

There is an infinite number of individual myth, but only a finite number - in fact a very small number - of species of myths. These latter express the human bewilderment about why we are here and where we are going, and include the myths of creation, of fall, of exodus and migration, of the destruction of the human race in the 
past (deluge myths) or the future (apocalyptic myths), of redemption in some phase of life during or after this one, however "after" is interpreted. (33)

Ed eccoci allora nel secondo capitolo, "Concern and Myth", a discutere quel "myth of concern" che è la fonte dell'energia creativa dell'uomo. Due sono gli elementi di base che chiariscono il concetto: la natura onniavvolgente del mito, la sua costante ri-creazione in ogni prodotto letterario. Di entrambi si parla in "The Koine of Myth: Myth as a Universally Intelligible Language", saggio di apertura di Myth and Metaphor, ma va segnalato anche il prezioso volumetto Creation and Recreation. Il "concern" è la preoccupazione, il bisogno che l'uomo sente di riaffermare continuamente la sua identità. Frye distingue tra bisogni primari e bisogni secondari; essi sono descritti in questo capitolo come nel quarto. I bisogni primari diventano poi oggetto di trattazione dettagliata nell'intera seconda parte del volume. La definizione più concisa, cui ora ricorro, è tratta da un saggio di Myth and Metaphor, "Literary and Linguistic Scholarship in a Postliterate World":

There is primary concern, and there is sccondary concern. Primary concern is based on the most primitive of platitudes: the conviction that life is better than death, happiness better than misery, freedom better than bondage. Secondary concern includes loyalty to one's own society, to one's religious or political beliefs, to one's place in the class structure, and in short to everything that comes under the general heading of idcology. All through history secondary concerns have had the greater prestige and power. We prefer to live, but we go to war; we prefer to be free, but we keep a large number of pcople in a second-class status, and so on. In the twentieth century the danger of persisting in the bad habits of war, and of the exploitation both of human beings and nature, have brought humanity to a choice between survival and extinction. If we choose survival, the twentieth century will be the first period in history when primary concern have some real chance of becoming primary.

Poets are the children of concern: they normally reflect the ideologies of their times, and certainly they are always conditioned by their historical and cultural surroundings. Yet there has always been a sense of something else that eludes this kind of communication. (Myth and Metaphor 21)

Il "qualcos'altro" che va al di là dell'ideologia del tempo è l'oggetto del capitolo successivo, "Identity and Metaphor". Dove si parla della metafora, pietra angolare del mondo ipotetico costituito dalla letteratura, e della sua funzione che è quella di dare all'uomo il riconoscimento del suo potere creativo, la sua identità, in questo universo di parole. È ancora d'obbligo qui un riferimento a un saggio "propedeutico" di Myth and Metaphor, "The Expanding World of Metaphor" (108-123). È notevole che nella dinamica secondo cui si svolge questo processo di identificazione nel fruitore di letteratura, Frye si esprima in termini contrastanti rispetto a quelli adottati in un simile contesto dal "much beloved colleague Marshall McLuhan" (Myth and Metaphor 237):

The act of reading, or its equivalent, consists of two operations that succeed one another in time. We first follow the narrative, from the first page or line to the last; once 
this pursuit of narrative through time is complete, we make a second act of response, a kind of Gestalt of simultaneous understanding, where we try to take in the entire significance of what we have read or listened to. The first response is conventionally one of the listening ear, even if we are reading a written text. The association of the second response with visual metaphor is almost inevitable. (69)

Diversi sono i referenti sensoriali (per McLuhan si va dalla vista all'udito nell'esperienza gestaltica), ma l'approdo alla comprensione simultanea che è la radice della conoscenza è identico. Non paia ozioso ricordare qui l'altro massimo esponente della cultura canadese del ventesimo secolo, ché Myth and Metaphor, per restare nell'ambito della presente discussione, è denso di riferimenti al suo lavoro.

Il quarto capitolo, "Spirit and Symbol", con cui si conclude la prima parte del volume, si apre con una breve riconsiderazione dei quattro linguaggi presentati all'inizio per indicare l'esigenza di identificarne un altro, il kerigma, cioè il linguaggio proprio della Bibbia, che si pone al di là di quello immaginativo e poetico e che comprende, con esso, anche tutti gli altri livelli di linguaggio. Il termine, già usato in The Great Code (29-30, 231), è associato al lavoro del teologo Rudolf Bultmann che comunque lo adotta in una accezione troppo ristretta secondo Frye:

Bultmann contrasts it [kerigma] with myth, and regards the mythical elements in the Bible as something to be removed or trasmuted into something else before the kerigma can stand out. As the entire Bible, from the first chapter of Genesis to the twenty-second chapter of Revelation, is written in the language of myth and metaphor, with occasional divergences into other modes, this would be difficult to do. If it were possible, we should be back to our old situation: kerigma would be simply a form of ordinary rhetoric, with the theologian adding a skeleton of his own dialectic (or pseudo-dialectic), the literary element being regarded as left in the Bible by inadvertence or simply to make it more fun to read. I think it is important to keep the word kerigma, but it has to mean not ordinary rhetoric but a mode of language that takes accont of the mythical and literary qualities which cannot be separated from the Biblical texture. (101-102)

Il livello del simbolo, dell'interpretazione della parola, qui è lo spirito, che suggerisce una realtà che non è propriamente né soggettiva né oggettiva perché è l'una e l'altra allo stesso tempo (128). Il germe metaforico, "the metaphorical kernel" dello spirito, è l'aria che respiriamo e questa è parte di noi in quanto è soggettivizzata dal nostro corpo, ma è anche dell'intera comunità in quanto è indispensabile per ogni altro essere vivente (126). È allora affidato allo spirito il compito di rappresentare uno stato di consapevolezza della propria identità umana, sia in ambito individuale che sociale. L'iniziativa nascosta in questo linguaggio è il senso della realtà ultima in cui scompare la distinzione tra soggetto e oggetto, idealismo e materialismo. Se tale senso è centrale nella parola della Bibbia, e cioè nell'umano linguaggio del kerigma che solo tratta della sacralità dell'immaginazione che ci permette di riconoscere la nostra autentica identità, sarà nella stessa Bibbia che si 
potranno cercare le risposte a quelli che abbiamo definito "bisogni primari". Il kerigma, come abbiamo visto, non scavalca il mito e la metafora ma ci passa attraverso incorporandoli; ciò vuol dire che la Bibbia "comprende" la letteratura e che il suo linguaggio è anche il linguaggio della letteratura.

Da qui si può già intuire il contenuto della seconda parte del volume: ognuno dei restanti quattro capitoli è dedicato alla definizione di un "primary concern". La Bibbia serve da codice mitologico, mentre la letteratura occidentale da campo di indagine e di riscontri. È difficile immaginare un critico diverso da Frye di fronte a un programma del genere, ma è facile capire come Frye stesso, con tutto il suo incrollabile e ispirato senso di direzione e con tutta la sua prodigiosa operosità, abbia praticamente impiegato tutta la vita per giungere a una sintesi di questa portata.

I quattro bisogni primari dei quali si discute nella seconda parte "Variation on a Theme", in cui il tema è ovviamente il "myth of concern", sono: agire, amare, assimilare l'ambiente, creare. Ognuno dei quattro capitoli è identificato da un emblema posto nel titolo. Il primo è "la montagna" e l'esemplificazione va dalla scala di Giacobbe al Purgatorio di Dante, a Milton, alla torre con scala elicoidale di Yeats. Tra i saggi di Myth and Metaphor è utile considerare, nell'ambito di questa prima "variazione", "The Journey as Metaphor" (212-226). Emblema della seconda "variazione" è "il giardino": dalla più antica versione della creazione della Genesi e dal Cantico dei Cantici Frye ci riporta ancora a Dante, e poi l'esemplificazione si sposta su Marvell, Donne, Ezra Pound, D.H. Lawrence. Una diretta anticipazione di questo capitolo è costituita dal saggio "The Survival of Eros in Poetry" (Myih and Metaphor 44-59). Mentre in questi due capitoli, sesto e settimo, sia la scala di Giacobbe che quella neoplatonica indicavano bisogni primari metaforicamente espressi con un movimento di elevazione, negli ultimi due capitoli le metafore di riferimento indicano una direzione opposta; si parla perciò di "scavo" nella coscienza individuale e collettiva.

L'emblema del settimo capitolo è "la caverna". Qui l'ispirazione viene direttamente da Blake, o meglio dalla sua cosmologia con cui praticamente si rovescia quella tolemaica. Abbiamo quindi, nella posizione più alta di questo nuovo mondo, la "alienation imagery of 'outer space,' usually thought of as dead or mechanical", mentre in quella più bassa "a point of identity where human creation and imaginative power start, often symbolized as under the sea, like Atlantis" (248). Questo è il punto in cui si attualizza l'oracolo di Delfi, "conosci te stesso", e in cui la Parola si fonde con lo Spirito (il maiuscolo è d'obbligo, spiega Frye) come in Finnegans Wake, "the only book I know which is devoted entirely to this hidden intercommunion of Word and Spirit, with no emergence into the outside world at any point, but of course the creative energy involved has produced all literature" (251).

La quarta "variazione" è posta sotto l'emblema della "fornace". Il fuoco è quello di Prometeo, che sfida gli dei e segna con il suo furto l'inizio della civiltà. Il bisogno primario che qui si rivela nel codice della Bibbia come 
nella letteratura è la proprietà, intesa come la cosa che è propria dell'uomo, e cioè la "naturale" espressione del suo potere creativo (303-304). Il mito dichiara la sua essenza come energia verbale, pura forma senza contenuto (291) che quindi si pone al di là delle parodie demoniche e degli adattamenti ideologici (293). Il potere del mito così inteso è allora espressione della massima ambizione dell'uomo, è il suo "concern of concerns" che può solo operare nel suo proprio contesto di saggezza e amore di cui il vertice della scala platonica come la nuova Gerusalemme di Blake sono esempi; "power outside that context operates only in hell" (308). Notevole a questo punto la critica a Nietzsche:

Nietzsche felt that he was completing the Promethean revolution against the sky-god by grounding human nature in a will-to-power. But Nietzsche's will-to-power does not distinguish demonic power, which uses words only to rationalize its brutality, from titanic or creative power, which is articulated in the arts and sciences and transforms the world through them. Being highly articulate himself, Nietzsche had little notion of what a will-to-power without words would lead to. Hence, though he himself was not anti-Semitic or racist, his social influence could produce only some kind of Nazism. (308)

Il potere titanico del mito consiste nel riconoscimento della umana partecipazione nella creazione del mondo. Per esempio definitivo Frye ricorre al Libro di Giobbe ("anyone interested both in the Bible and literature will eventually find himself revolving around the Book of Job like a satellite" [310]), o meglio alla illuminazione di Giobbe cui Dio ripropone la straordinaria potenza della creazione.

When the infinitely remote creation is re-presented to him, he becomes a participant in it: that is, he becomes creative himself, as heaven and earth are made new for him. He is given no more discovery, but gains a deeper apprehension of what is already there. This deeper apprehension is not simply more wisdom, but an access to power. Myths of a paradise lost in the past or a hell threatening us after death are myths corrupted by the anxieties of time. Hell is in front of us because we have put it there; paradise is missing because we have failed to put it there. The Biblical perspective of divine initiative and human response passes into its opposite, where the initiative is human, and where a divine response, symbolized by the answer to Job, is guaranteed. The union of these perspectives would be the next step, exept that where it takes there are no next steps. $(312-313)$

Riferimenti pertinentissimi al contenuto di questo ultimo capitolo sono, ancora in Myth and Metaphor, nei seguenti saggi: "The Mythical Approach to Creation" (238-254), "Blake's Bible" (270-286) e "Cycle and Apocalypse in Finnegans Wake" (356-374).

Per concludere, se un'ombra di staticità, di mancanza di spazio d'azione, dall'ultima frase "there are no next steps" si volesse inferire, occorre subito rettificare. La creazione non è un atto finito ma infinito; creare è ri-creare il 
mito di Prometeo che ricertifica l'identità dell'uomo. Per questo, con Calvino delle Lezioni americane (Six Memos), Frye ripete che "literature remains alive only if we set immeasurable goals, far beyond all hope of achievement" (xxiii), e con McLuhan di Through the Vanishing Point, che "a man's reach must exceed his grasp or what's a metaphor?" (Myth and Metaphor 237).

\section{University of Toronto}

\section{OPERE CITATE}

Ayre, John. Northrop Frye: A Biography. Toronto: Random House, 1989.

Calvino, Italo. Six Memos for the Next Millennium. Cambridge, Mass.: Harvard UP, 1985.

Denham, Robert D. Northrop Frye: An Annotated Bibliography of Primary and Secondary Sources. Toronto: U of Toronto P, 1987.

Northrop Frye. Words with Power: Being a Second Study of "The Bible and Literature." Markham, Ontario: Viking-Penguin Books Canada, 1990.

Myth and Metaphor: Selected Essays 1974-1988. Ed. Robert D. Denham. Charlottesville and London: U of Virginia P, 1990.

1982.

The Great Code: The Bible and Literalure. Toronto: Academic Press Canada, Anatomy of Criticism: Four Essays. Princeton: Princeton UP, 1957.

Creation and Recreation. Toronto: U of Toronto P, 1980.

Fearful Symmetry: A Study of Wiliam Blake. Princeton: Princeton UP, 1947.

Mito metafora simbolo. Trad. di Carla Pezzini Plevano e Francesca Valente Gorijup. Roma: Editori Riuniti, 1989.

The Critical Path: An Essay on the Social Context of Literary Criticism. Bloominglon and London: Indiana UP, 1971.

McLuhan, Marshall. Through the Vanishing Point: Space in Poetry and Painting. New York: Harper \& Row, 1969.

Salusinszky, Imre. Criticism in Society. Interviews with Jacques Derrida, Northrop Frye, Harold Bloom, Geoffrey Hartman, Frank Kermode, Edward Said, Barbara Johnson, Frank Lentricchia, and J. Hillis Miller. New York and London: Methuen, 1987. 